\title{
The shifting roles of employers: at the intersection of employment and social work. A case study from Norway
}

\author{
Janne Paulsen Breimoํㅡ, Cecilie Høj Anvik², and Terje Olsen ${ }^{3}$
}

\begin{abstract}
Active labour market policies (ALMPs) are often seen as a panacea for dealing with labour market exclusion, especially when it comes to young people with mental health issues. Such policies demand considerable involvement from employers, placing more responsibility in their hands. Yet, there remains a notable knowledge gap concerning the actual role that employers play in processes of inclusion in the labour market. In this article, we provide knowledge about what employers do in order to include young people with mental health issues into the workforce, what roles they play in these processes, and what motivations underlie their endeavours. We argue that, due to organizational changes to occupational rehabilitation in Norway, employers must increasingly occupy a vacancy left open by social workers. While this situation has demanded further responsibility from employers, they are quite often insufficiently educated or trained to deal with such issues. We address what consequences this could have for young people with mental health issues striving to enter the labour market.
\end{abstract}

Keywords: active labour market policy; inclusion; young people with mental health issues; employers; occupational rehabilitation; Norway

1. Professor in Social Work, Nord University, Norway

2. Associate Professor in Sociology, Nord University, Norway

3. Research Director, Fafo Institute of Labour and Social Research, Oslo, Norway

Address for correspondence: janne.i.breimo@nord.no

Date of first (online) publication: 9th August 2021

Funding details: The research was funded by the Norwegian Labour and Welfare Administration through a Research and Development grant 


\section{Introduction}

Active labour market policies (ALMPs) have gained support in recent years and are frequently prescribed for securing successful activation strategies. Researchers claim, however, that the role of employers in this paradigm shift has often been neglected both in research (Ingold \& Stuart, 2015; Benda et al., 2020) and in social policy more broadly (Farnsworth, 2004). The few studies conducted to date conclude that employer involvement is crucial for success with active labour market policies (Ingold \& Stuart, 2015). Furthermore, evidence suggests that ALMPs demand more engagement from employers, expanding their responsibility for outcomes of vocational training and rehabilitation (Bredgaard, 2018). Still, there remains a notable knowledge gap concerning the actual role that employers play in processes of inclusion in the labour market. This article reports on a project which investigated the role of employers in including one of the most vulnerable groups on the labour market: young people with mental health issues. As such, the article provides knowledge about the actions and functions of employers when trying to include this group of people in the labour market and what roles they play in these processes. The research question at the core of this investigation is: What is the impact of ALMPs on the employer role and what consequences might these changes entail?

\section{Background}

In Norway, more and more people find themselves outside of the labour force, and an increasing number of people need support in order to (re) enter the labour market. Especially for young people with mental health issues, employment is characterised as an important means to recovery (Bond et al, 2016; Heitmann \& Kydland, 2017). Providing work training on the job ('place then train') has proven to be more efficient for securing employment than pre-training in a sheltered environment ('train then place'). However, including young people with mental health issues in the labour force has proven difficult. By the end of March 2019, 25200 individuals under the age of 25 received a work assessment allowance (AAP), which is $2.7 \%$ of this population. Among these beneficiaries, those with mental health problems made up the largest proportion (74\%) of the group (Grønlien, 2020). Moreover, the number of individuals under the age of thirty who collected AAP increased from $22.5 \%$ in 2014 to $26.5 \%$ in 2018 . This data also reveals that for those who became ineligible for further AAP (after three years of receiving it), an increasing number of them were young people with mental health problems who end up on welfare benefits (Lima \& Grønlien, 2020). The Norwegian government has called for collective action to solve this wicked problem, asserting that co-creation of labour market efforts are needed. In particular, employers are expected to assume their share of the responsibility to 
include a wide range of persons with disabilities into the labour market. But the specific essence and complexities of this responsible employer role has, with only some exceptions, been neglected.

The Nordic Model is known for, among other things, a tripartite collaboration in working life; the three parties encompass the government, employers represented by employers' organisations, and workers represented by trade unions. This collective sharing of risk and responsibility has led to relatively small wage differences, better health and safety regulations, and more work-life inclusion. Supported Employment (SE) was first introduced to Norway at the start of the 1990s (Spjelkavik, 2012). It comprehends service provisions through which people are assisted with obtaining and maintaining employment on the ordinary labour market. The philosophy behind SE was to 'place then train', rather than to 'train then place', which had been the traditional protocol. Research has demonstrated that close contact with a competent job coach was important for successful inclusion (Spjelkavik, 2012). The needfulness of this kind of employer support is consistent with the fact, marked by Andreassen and Fossestøl (2014) that Norwegian government imposes high demands on employers, expecting rehabilitation to coincide with labour- market entry.

Previously, the task of including persons with disabilities into the Norwegian work force was regulated and motivated by the Letter of intent for a more inclusive working life (IA- avtalen 2014-2018). In 2018, during the renewal of this letter, the second sub-objective concerning the inclusion of disabled people was withdrawn and replaced by an 'inkluderingsdugnad' (regjeringen.no). 'Dugnad' is the Norwegian term for 'volunteer work', however it has a specific historical meaning and cultural resonance; it signifies coming together and contributing to the community or to a local association of affiliation, for instance a neighbourhood cooperative or a sport's organisation. It is embedded in the national identity and seen as a drive for personal duty. The government launched this 'dugnad' to signal that the work of generating a truly inclusive labour market must be divided among the tripartite collaborators: the government, the trade unions, and the employers. The Norwegian government has begun introducing measures that motivate employers to hire more persons with disabilities, with psychiatric health problems, and with substance abuse issues. Behind this, there is an objective to ensure that $5 \%$ of the government workforce comprises persons with disabilities, or persons who have a 'gap' in their resumes (those who have been out of work for some time 'without a good reason'). This political initiative could be categorised as what researchers call the 'co-creation of public policy'. The concept of 'co-creation' can be defined as an effort to involve citizens and other stakeholders as responsible partners in public problem solving and value production. It is a process through which two or more public and/or private actors attempt to solve a shared problem or task through a constructive exchange of different kinds of knowledge, resources, competences, and ideas that enhance the production of public value (Voorberg et al., 2015). Still, some researchers have maintained that, occasionally, co-creation does not lead to a production of public value, but rather 
a co-destruction of value (Plé \& Chumpitaz Cáceres, 2010; Wu, 2017). Voorberg et al. (2015) claims that citizens are most often studied as co-implementors, not codesigners of policies. From a more critical angle, co-creation could be considered a responsibilisation of non-state actors. Nilssen and Kildal (2009), for instance, assert that the use of welfare contracts can be viewed as a new form of control technology that changes the balance between service worker and service user, making the latter more dependent on the former. In this case, it could be argued, that the co-creation of vocational rehabilitation puts larger responsibility on employers, which in turn could alter the chains of accountability.

\section{Changing work modes of frontline social workers}

Either way, making non-public stakeholders responsible for implementing policy has some consequences. Upon interviewing employers about their attitudes towards hiring young people with mental health issues, and about the work they do in this regard, we found that many of the activities undertaken resemble those traditionally performed by social workers.

Social work is both a profession and an academic discipline. The major international social work organisations have agreed on a common definition of social work:

Social work is a practice-based profession and an academic discipline that promotes social change and development, social cohesion and the empowerment and liberation of people. Principles of social justice, human rights, collective responsibility and respect for diversities are central to social work. Underpinned by theories of social work, social sciences, humanities and indigenous knowledge, social work engages people and structures to address life challenges and enhance well-being. (International federation of social workers (IFSW))

Still, many scholars find that social work, as a profession, is under pressure. Lindqvist and Lundälv (2018) allege that activation policies in general have changed the work modes of frontline caseworkers, explaining that the work they do has become 'administrative work to be performed according to bureaucratic principles'. For instance, Hanssen et al. (2015) argues that an understanding of the complexities of human struggle is fading, which consequently impairs the forms of knowledge and practice central to social work. Furthermore, Jönsson (2015) adds that social workers are increasingly becoming bureaucratic agents of social control. In Norway this transition is partially seen as a result of an administrative reform in 2005 that merged the former central Norwegian government employment and national insurance administration agencies and of a formal collaboration agreement between 
different agencies of the local government social services administration, which resulted in the establishment of the Norwegian Labour and Welfare Administration (NAV). Lundberg and Syltevik (2016) call this reorganisation 'an extreme example of a one-stop-shop'. The reason for this is that it manages nearly all benefits and allowances in the Norwegian welfare system. Observers have contended that this establishment has fundamentally changed the conditions for social workers in Norway (Solstad, 2018); indeed, Røysum (2017) concludes that 'the establishment of a holistic one-stop-shop agency giving social workers substantial responsibility for finding individual solutions in combination with few exit options appeared to work against the practice of social work'. Røysum (2013) also demonstrates that social workers in NAV have experienced an increase in administrative work and a decrease in time for client follow-up. At the international level, researchers acknowledge that the activation project's emphasis on conditionality and sanctions may challenge the professional service provision (McDonald \& Chenoweth, 2009).

Traditionally, social workers have played a key role in enabling young people with mental health issues (and other complex vulnerabilities) to navigate services and eventually employment (Munford $\&$ Sanders, 2020). The question remains: to what degree has this role now been transferred to employers? And if it has, what are the consequences of this shift? What happens to professional social work knowledge if social workers are increasingly becoming agents of bureaucratic control and if employers are adopting traditional social work practices? Drawing on twelve case studies in four Norwegian regions, we analyse the work inclusion processes for young adults with mental health issues. We argue that employers have been delegated much of the 'social work' and practical responsibilities associated with vocational rehabilitation.

\section{Methodology}

The empirical data in this study is based on twelve case studies in four separate Norwegian regions. The design of the study was based on a 'best practice' approach; the employers recruited were those known for their willingness for and skills at including young people with mental health issues in the workplace. Bredgaard (2018) provides a typology of four different kinds of employers: the committed employer, the dismissive employer, the sceptical employer, and the passive employer. In our project we have recruited 'committed employers' exclusively. Such committed employers are known by their positive attitude and their active participation in ALMPs (Bredgaard, 2018) The committed employers in this study were selected by four 'Working life centres', who also introduced us to them. The reason for choosing 'model' employers was that it provided an opportunity to study tangible instances of the successful integration of 'difficult-to-hire' job seekers. In each case we interviewed managers, 
HR advisers, and middle managers, as well as service workers at NAV and advisors at the Working life centres. The interviews were conducted as open, semi-structured interviews, at their workplaces. The primary focus of the employer interviews was on their experiences with and perspectives on hiring young people with mental health issues for their workplace. Attention was directed to studying what the employers do - or what they say that they do - as well as why they do what they do when they consider young people for employment or for work practice at their businesses. The primary focus of the interviews with service workers from NAV and with the advisors from the Working life centres was on their experiences with these employers, on how they collaborate with them, and on how responsibility is divided between them and the employers.

A total of twenty-two interviews were administered with altogether twentyfive informants. The interviews were mainly conducted individually, but in some instances it was most convenient to interview two informants together. Usually the interviews lasted from one to two hours, and they were audio-recorded and transcribed verbatim. These transcripts were imported and analysed in NVivo. The researchers involved all had access to the data files and held regular meetings to examine the coded material throughout the course of data analysis and during the writing process. The data was searched for information on what the employers actually did for the inclusion of young people in their work force, why they did it, and what they felt about doing it. The goal was not to perform a comparative analysis across cases, but rather to develop a general overview of the tasks and experiences related to the inclusion of this group of young people in the workplace.

The cases constitute the main unit of analysis, and all cases were classified in terms of background variables (number of employees, branch and sector). Reading systematically through the interviews, certain socio-cultural features of the employers were recognized and coded. These were: 1) employers' attitudes towards hiring young people with mental health issues, 2) the degree of employers' systematic training and development of the candidates, 3) the employers' collaboration with NAV (degree of expressed mutual trust), 4) the routines for follow-up of from colleague at the workplace (in terms of how close), and finally 5) employers' policies for explaining (or not) to colleagues about the person's mental health issues, or problems that likely would occur. These categories have been used as an analytic grid for discussing how employers take on new forms of responsibilities as 'inclusive workplaces'.

There are some limitations to this study. The fact that we only interviewed what Bredgaard (2018) designates as 'committed employers' means that we do not know how other types of employers address the vocational rehabilitation of young people with mental health problems. In the following sections, we will present and analyse what these committed employers say that they do in order to include young people with mental health issues in their workplace, the challenges they encounter, and how they work to solve the problems attendant on this inclusion process.

The study was approved by the Norwegian Centre for Research Data (NSD), which 
provides expertise and advice in data management, including legal and ethical issues related to privacy. Informed consent was provided from all interviewees prior to the interviews. The first contact with the employers were made by the personnel at NAV. We contacted the employers when they had given their permission to it. From the start, we were very specific that we did not want any information about the actual employees or candidates, and we have not collected names or any other personal information of employees. Although employers talked about their experiences with actual persons, which constitutes a third party in the study, we were careful not to register any information that could indirectly be traced back to real persons. For the same reason, we never mention the name of the employers or companies in the cases.

\section{Being there and being close}

In large enterprises, following up with young people who are either hired or on work-training placements is usually carried out by middle managers or by hired 'mentors', whereas in small enterprises it is often done by the manager themselves. In either case, the employers we interviewed all emphasised the importance of being close to the young 'participants' and of building up trust over time. When asked about what 'makes it work', they all answered with the same sentiment- that 'it's the little things, a pat on the back, asking how they're doing, are you ok? It's all about relations':

Being close, showing that someone cares. I think it is important to be an adult who is there for them and helping them to start thinking differently. To be sort of a mum.

All of the employers we interviewed reported that they assume great responsibility and do much more than one would typically expect from an employer. In the small companies, the managers often had a personal motivation for putting in a special effort for these young people; some of them reported that they had relatives who were in a similar position, or that they felt a moral obligation to include vulnerable young people in the labour force. Some of them stressed that doing this also has an effect on the working climate in general. Furthermore, most of them were also very critical of NAV and of their commitment to young people. Indeed, service workers at NAV admitted that they do not have the resources to follow these young people as closely as they would like. One executive manager at a work place spoke about her middle managers in this way:

I think that small enterprises often become safe work environments for those who have found themselves outside of the labour force for some time, especially young 
people. And the managers are close, which makes them good mentors, without being defined as such, but they are good mentors for those who need extra follow-up. They might not have a master's degree, but they are good with people and they are close.

She acknowledges the fact that her managers might not be educated or trained to support these young people, but by working so closely with them the managers have a unique opportunity to serve as an alternative to the vocational advisors at NAV. Being there and being close is not only a matter of watching over young people, but also providing them with working-life role models (Bond et al., 2016).

\section{To tell or not to tell}

Including young people with mental health problems in the workplace introduces some challenges for employers, and those we interviewed had mixed attitudes about how to deal with the issue of mental health problems. One of the questions raised was whether or not to foster an open environment of disclosure for such problems and whether or not employers should share or reveal this information

When young people come in here, it [mental health problems] is not a topic. I do not wish to and I do not need to know anything about your story. You start with a clean slate. Of course, if there's something I should know, then that's something else. But many of them have a story that hampers them or follows them, and then I think it is a good idea to start fresh. Still, we do have an understanding that everything might not be ok.

Another employer, argued that it was important to be open about this right from the start:

My experience is that the more open we are about this issue, the better results we get. Of course it is the candidate's own choice to decide whether to share or not, but usually I share the information that this person gives me permission to. For example I say that we have a young person here who struggles with social anxiety (?). Usually they grant me permission to say that. They understand that the reason why I want to share it is to reach the goals that we set. When you are anxious like that you tend to hide from people, but this is a shop and you have to meet people.

The employers make their own decisions about whether or not to be open about mental health issues and whether or not to push young people to disclose their situation to their co-workers. By being open, the employee might gain more acceptance and understanding from their colleagues. On the other hand, this might 
result in becoming permanently branded as 'the person with a history of mental health issues'. Still, this is an example of a dilemma that employers face, and one on which few are educated or trained to manage.

\section{Guiding, advising and doing 'outreach work'}

Including young people with mental health issues in an enterprise presents many different challenges for employers. Some of these youth have never been previously employed, and some are not familiar with the expectations and demands of working life. One of the executive managers argued that the employer or managers should be in a position to correct young people when they do something inconsistent with expected practices:

I have good managers who want them (the young people) there, they follow them closely and they let them know when things don't work or if they need to do something differently.

It is important for employees to be pointed in the right direction upon doing something 'wrong' before the situation escalates and causes problems that, perhaps, cannot be easily fixed. But, for some employers it is difficult to determine the reach of this responsibility and how to handle situations that they do not feel sufficiently competent to solve. One of the employers interviewed said of an employee:

He has adapted just fine now, but for a while he was all gone. He lived with his sister, in her basement. I couldn't get a hold of either him or his sister for a long time. I went home to their place, but there was no one there. I got scared, because I felt out of control.

This employer significantly internalised a responsibility to follow up with his hire. When the employee did not show up for work, the employer felt responsible to visit his home and search for him. Still, he felt uncertain about whether it was even 'his place' to do so. Another employer shared a story about a young girl that they hired:

She was very afraid when she first came here. She said that she was afraid to let us down. We said that she shouldn't worry about that. We will make sure that you don't. We will go according to your pace and you get to try things out. Some of them need a lot of time, while others jump right in.

Knowing when to push and when to hold back is a skill that employers need to master. For young people with mental health problems it is crucial that they get to do things at their own pace. Yet, sometimes a push might be necessary in order for the process to move forward. Research illustrates that this group of vulnerable 
youth often need support for a broad spectrum of issues (Frøyland, 2018). Some authors have identified this managerial skill as 'inkluderingskompetanse', or 'competence of inclusion' (Frøyland \& Spjelkavik, 2014). This competence consists of two components: firstly, knowledge of the user group and of supervision skills and, secondly, knowledge of how to use the workplace as a development arena for the participant. It could be argued that this places more responsibility on the workplaces and on the employers.

\section{Matching and preparing for work life}

For young people entering the labour market, one of the biggest challenges is the lack of work experience (Hardoy et al., 2017). Hence, being introduced to other employers and being connected to broader networks is of immense importance. Some of the employers who are unable to take on young people after their 'work training' report this as one of the things they offer as an alternative:

If I cannot take them in after the practice period, I help them to find other jobs. I use my network. I also help them write their CV's or otherwise with getting in position for a job. I prepare them for what they might expect, what they can do in order to find some sort of structure in their life, and how they should talk to people.

Matching is a well-known phenomenon in employment activities, and it is, according to Gustafsson et al. (2013), associated with what is called 'the broker society'. 'A broker society is one that is filled with services that are in one way or another associated with sales or in which various types of broker play an important role in the way the market operates' (Gustafsson et al., 2013, p. 100). Part of preparing young people for working life is pointing out to them what is expected of an employee. One employer mentioned that it was important to 'not treat them like kids'. Showing up for work every day and notifying the workplace if you are sick is one of the basic lessons that often needs to be learned, as expressed by one employer: 'some of these young people have never been required to take on responsibilities before they come here'. Hence, certain employers see it as their responsibility to teach young people basic working life skills that are important regardless of whether they will be permanently hired. One of the employers described how he once conveyed this message:

I have one requirement for you, and that is that you call me if you can't get to work one morning. If you can't make it at eight o'clock, call me. If you do not call - that is not acceptable. If you can't make it at eight we can agree upon a new time for you to show up. If you then still can't make it, that's ok but you need to call me. And he got that. 
The employers feel obligated to prepare young people for working life expectations. Many employers spoke about what kind of expectations should apply to employees. All agreed that it was vital to be specific and direct with expectations in order to succeed. At the same time, some acknowledged the need for flexibility surrounding working hours, and that it was important for employers to know exactly when to tighten the grip and when to loosen it.

Being outspoken about expectations not only applies to working hours, but also to general behaviour, customer relations, and types of work assignments. One employer illustrates the importance of allocating 'real work assignments':

In her last job she had been set to fold clothes in the back of the shop. For a whole year she had not moved out of there. When she came to me she was at the counter after 3 months.

This employer stated that to succeed with this group of employees, one must be brave and must give them a chance to prove their worth. Hiding them away by giving them easy tasks does not make their problems go away. They need to be taken seriously and to feel like ordinary employees. Still, this is yet another skill that employers need to learn: how far to push a person with mental health problems to take on challenges that may be scary or intimidating for them. Munford and Sanders (2020) argue that social workers need to be 'courageous, stand up for young people, and confront the conditions that marginalize them'. In the workplace, the conditions that marginalise young people with mental health issues could be strict working hours, or having to do work duties that are not considered 'real work tasks', or being put in situations that they are not equipped to handle.

\section{Concluding remarks}

Frøyland (2018) identifies four roles adopted by frontline workers assisting with job inclusion for vulnerable youth: administration and securing basic needs; connectionand relationship-building; job enabling; and job customisation. Lundberg and Syltevik (2016) argue that the establishment of NAV has created distance between the social workers who are employed there and their service users, especially since the digitalisation of services has moved contact from a physical frontline to a digital arena. We argue that the combination of more administrative-oriented social workers and of more government-imposed expectations on employers has changed the way that vocational rehabilitation is practiced. Employers use more of their time trying to motivate, encourage, and follow up with employees in order to keep them active on the labour market. They also utilise their networks to locate other jobs for those 
young people who cannot be hired after the 'practice time' is over.

Based on our findings from the interview study, we argue that these "committed employers" (Bredgaard, 2018), do lot of what we call social work, in the way they recruit and follow up young people with mental health issues. The employers interviewed are explicitly concerned with facilitating that young people who have so-called gaps in their CV to be able to get an employment in their business, and they are motivated by a sense, as well as a policy of socially responsibility. Despite the fact that such engagement is voluntary, there is a growing awareness from the government that as many employers and businesses as possible ought to take social responsibility for young adults outside of the labor marked. As mentioned in the introduction, the Norwegian inclusive working life policy and the 'inkluderingsdugnad' underlines that working life is the most important arena for integration and societal participation.

The question is, what happens to those professional values and ethical standards that traditionally have been maintained by social workers? There is a growing concern in professional social work discourses of what happens with the 'social' in social work and that social work as a profession is: 'About to be diluted through processes such as individualization, standardization and demands for evidence-based practice' ((Hanssen, Hutchinson, Lyngstad \& Sandvin, 2015, p. 115), with less space for social work and follow-up work. The welfare services responsible for the follow-up of users, spend more time on goal-oriented, bureaucratic tasks (Fossestøl, Breit $\&$ Borg 2016). This puts traditional social work related competence under pressure, and creates less direct follow-up and a greater distance to users (Øvrelid, 2018). The 'social' in social work is described not only as relational aspects between an user/ client and a welfare service professional, but also 'social' refers to an awareness of the structural, socio-material aspects that condition people's life challenges and well-being (Hanssen, et al., 2015). This tends to get lost when the daily activities of social workers are tied up in bureaucratic tasks and procedures, and hampers their opportunities of attending to the more structural aspects of peoples everyday lives. It also prevents them from being able to reflect on and act on structural power relations produced by and within the welfare state.

As for employers, they are usually not trained for handling employees with complex challenges and problems. Even though larger companies often have more developed HR departments, with more resources and knowledge available to facilitate potential training Hyggen \& Vedeler (2021), the majority of Norwegian companies are small or medium- sized. In one of the quotes above, an employer expressed that she needs to be 'sort of a mum'. This statement could be analysed as quite patronising, and it is not self-evident that all young people would feel comfortable having an employer who acts 'like a mum'. Employers are in a position of power, since they have the ability to hire or fire, not to mention their other impacts on the working conditions for a young adult. Another urgent question to answer would be what consequences, then, are introduced to employees who do not have committed employers. If employers, in general, now have more responsibility for vocational 
rehabilitation, it is likely that some job seekers will have much better conditions for success than others, depending on the commitment of their employer. We suggest that more research is needed in order to determine the consequences of these changes in vocational rehabilitation practice.

\section{References:}

Andreassen, T. A., \& Fossestøl, K. (2014) Utfordrende inkluderingspolitikk: Samstyring for omforming av institusjonell logikk i arbeidslivet, helsetjenesten og NAV [Challenging inclusive policy using governance to transform institutional logic in working life, health services, and the Norwegian Labour and Welfare Administration]. Tidsskrift for samfunnsforskning, 55, 2, 174-202. https://doi.org/10.18261/issn.1504-291X

Benda, L., Kosta, F., \& Van der Veen, R. (2020) Activation is not a panacea: Active labour market policy, long-term unemployment and institutional complementarity. Journal of Social Policy, 49, 3, 483-506. https://doi.org/10.1017/S0047279419000515

Bond, G. R., Drake, R. E., \& Campbell, K. (2016) Effectiveness of individual placement and supported employment for young adults. Early Intervention in Psychiatry, 10, 4, 300-307. https://doi.org/10.1111/eip.12175

Bredgaard, T. (2018) Employers and active labour market policies: Typologies and evidence. Social Policy and Society, 17, 3, 365-377. https://doi.org/10.1017/S147474641700015X

Farnsworth, K. (2004) Corporate power and social policy in a global economy: British welfare under the influence. Policy Press.

Fossestøl, K., Breit, E. \& Borg, E. (2016) Hvorfor lykkes ikke NAV- kontorene med å jobbe mer arbeidsrettet? Søkelys på arbeidslivet, 1-2 (17, 5 - 23, DOI: 10.18261/issn.1504-79892016-01-02-01

Frøyland, K. (2018) Vital tasks and roles of frontline workers facilitating job inclusion of vulnerable youth. European Journal of Social Work, 22, 4, 563-574. https://doi.org/10.10 80/13691457.2018.1423547

Frøyland, K., \& Spjelkavik, Ø. (2014) Inkluderingskompetanse: Ordincert arbeid som mål og middel [Inclusion competence: Ordinary work as goal and means]. Gyldendal akademisk.

Grønlien, E. (2020) Utviklingen i mottakere av arbeidsavklaringspenger og personer med nedsatt arbeidsevne per 30. juni 2020 [The development of recipients of work assessment allowance for persons with low work ability, per 30 June 2020]. NAV Arbeids- og velferdsdirektoratet / Statistikkseksjonen. https://www.nav.no/no/nav-og-samfunn/statistikk/aap-nedsattarbeidsevne-og-uforetrygd-statistikk/arbeidsavklaringspenger

Gustafsson, J., Prieto Peralta, J., \& Danermark, B. (2013) The employer's perspective on supported employment for people with disabilities: Successful approaches of supported employment organizations. Journal of Vocational Rehabilitation, 38, 2, 99-111. https://doi. org/10.3233/JVR-130624

Hanssen, J. K., Hutchinson, G. S., Lyngstad, R., \& Sandvin, J. T. (2015) What happens to the social in social work? Nordic Social Work Research, 5, 1, 115-126. https://doi.org/10. 
1080/2156857X.2015.1060895

Hardoy, I., Røed, K., von Simson, K., \&Zhang, T. (2017) Effekter av arbeidsmarkedspolitikk rettet mot ungdom i Nord-Europa - en meta-analyse [Effects of labour market policies for youth in Northern Europe - a meta-analysis]. Søkelys på arbeidslivet, 34, 3, 167-181. https://doi.org/10.18261/issn.1504-7989-2017-03-02

Heitmann, L., \& Kydland, R. (2017) Arbeidsplassen som tilfriskningsarena [The workplace as recovery arena]. Tidsskrift for psykisk helsearbeid, 14, 2, 178-184. https://doi.org/10.18261/ issn.1504-3010-2017-02-09

Hyggen, C. \& Vedeler, J. (2021) Employer Engagement and Active Labour Market Policies. Evidence from a Norwegian Multi- Method Study. Social Policy and Society; 1-13, https:// doi.org/10.1017/S1474746420000421

IA- avtalen 2014- 2018. Intensjonsavtale om et mer inkluderende arbeidsliv. 4. mars 201431.desember 2018

International federation of social workers (IFSW) Retrieved 30.9.2020 from: https://www.ifsw.org/what-is-social-work/global-definition-of-socialwork/\#: :text=\%E2\% 80\%9CSocial\%20work\%20is\%20a\%20practice-based $\% 20$ profession\%20and\%20an,respect $\% 20$ for $\% 20$ diversities $\% 20$ are $\% 20$ central\%20to\%20 social\% 20 work.

Ingold, J., \& Stuart, M. (2015) The demand-side of active labour market policies: A regional study of employer engagement in the work programme. Journal of Social Policy, 44, 3 , 443-462. https://doi.org/10.1017/S0047279414000890

Jönsson, J. H. (2015) The contested field of social work in a retreating welfare state: The case of Sweden. Critical and Radical Social Work, 3, 3, 357-374. https://doi.org/10.1332/ $204986015 X 14417170590583$

Lima, I., \& Grønlien, E. (2020) Flere mottar uføretrygd og sosialhjelp etter innstramming i AAP-regelverket [More people receive disability benefits and welfare benefits after AAP austerity measures]. Arbeid og Velferd, 2, 61-79.

Lindqvist, R., \& Lundälv, J. (2018) Activation, medicalisation and inter-organizational cooperation in health insurance - implications for frontline social work in Sweden. European Journal of Social Work, 21, 4, 616-627. https://doi.org/10.1080/13691457.201 7.1293010

Lundberg, K. G., \& Syltevik, L. J. (2016) Everyday interaction at the front-line: The case of the Norwegian all-in-one bureaucracy. Journal of Organizational Ethnography, 5, 2, 152-166. https://doi.org/10.1108/JOE-12-2015-0026

McDonald, C., \& Chenoweth, L. (2009) (Re)shaping social work: An Australian case study. The British Journal of Social Work, 39, 1, 144-160. https://doi.org/10.1093/bjsw/bcm094

Munford, R., \& Sanders. J. (2020) Transformative practice: Social work practice with vulnerable young people. European Journal of Social Work. Advance online publication. https://doi.org/10.1080/13691457.2020.1819205

Nilssen, E., \& Kildal, N. (2009) New contractualism in social policy and the Norwegian fight against poverty and social exclusion. Ethics and Social Welfare, 3, 3, 303-321. https:// doi.org/10.1080/17496530903209550 
Plé, L., \& Chumpitaz Cáceres, R. (2010) Not always co-creation: Introducing interactional co-destruction of value in service-dominant logic. Journal of Services Marketing, 24, 6, 430-437. https://doi.org/10.1108/08876041011072546

Røysum, A. (2013) The reform of the welfare services in Norway: One office - one way of thinking? European Journal of Social Work, 16, 5, 708-723. https://doi.org/10.1080/1369 1457.2012 .722982

Røysum, A. (2017) 'How' we do social work, not 'what' we do. Nordic Social Work Research, 7, 2, 141-154. https://doi.org/10.1080/2156857X.2017.1284150

Solstad, A. (2018) Kort om NAV [Short on the Norwegian Labour and Welfare Administration]. Universitetsforlaget.

Spjelkavik, $\varnothing$. (2012) Supported employment in Norway and in the other Nordic countries. Journal of vocational Rehabilitation, 37, 3, 163-172. https://doi.org/10.3233/JVR-2012-0611

Voorberg, W. H., Bekkers, V. J. J. M., \& Tummers, L. G. (2015) A systematic review of co-creation and co-production: Embarking on the social innovation journey. Public Management Review, 17, 9, 1333-1357. https://doi.org/10.1080/14719037.2014.930505

$\mathrm{Wu}, \mathrm{L} .-\mathrm{W}$. (2017) The bright side and dark side of co-production: A dyadic analysis. Management Decision, 55, 3, 614-631. https://doi.org/10.1108/MD-11-2016-0789

Øvrelid, B. (2018) Profesjonsidentitetens vilkår. Tidsskrift for velferdsforskning, 2, 21, 103-118. 